\title{
STRUCTURAL ASSESSMENT OF THE BRIDGE № M 044 AT THE END OF RYBNIČNÁ STREET ABOVE THE ROAD II/502 BRATISLAVA-PEZINOK
}

\author{
${ }^{1}$ Paulik P., Ph.D., Associate Professor, \\ peter.paulik@stuba.sk, ORCID: 0000-0003-1051-3988 \\ ${ }^{1}$ Slovak Technical University in Bratislava \\ Radlinského 11, Bratislava, 81005, Slovak Republic \\ ${ }^{2}$ Chernieva O., Ph.D., Associate Professor, \\ chernieva@ogasa.org.ua, ORCID: 0000-0002-4807-6421 \\ ${ }^{2}$ Odesa State Academy of Civil Engineering and Architecture \\ Didrihsona 4, Odesa, 65029, Ukraine
}

\begin{abstract}
The paper is focused on the results of the survey and diagnostics of the bridge № M 044 at the end of Rybničná street above the road II/502 Bratislava-Pezinok in the Slovak Republic. The article is the result of the cooperation between the Department of Concrete Structures and Bridges of the Slovak Technical University in Bratislava and the Department of Reinforced Concrete Structures and Transport Facilities of the Odessa State Academy of Civil Engineering and Architecture within the framework of the National Scholarship Program of the Slovak Republic. Data were obtained to assess the technical condition of the structures and the bridge as a whole. As a result of the inspection, the type of destruction of each structural element of the frame and superstructure was determined. A study on the content of chloride-ionic contamination of concrete and non-destructive tests of strength parameters was carried out. A detailed research analysis of the results and recommendations for processing the reconstruction has been proposed. In accordance with the valid regulations, due to the significant deformation in the horizontal plane, the cause of which is not known and due to the gradual loss of the bearing function, we evaluate the construction, and technical condition by the degree: VI very bad, and immediate reconstruction is required.

The service life of the bridge is mainly affected by corrosion and displacement of the bearings, as well as contamination of concrete with chlorides from sanding salts and corroded bearings. Corrosion of the reinforcement in the horizon of 5 years can negatively affect the loadbearing capacity of the bridge and there is also an increased risk of falling pieces of the covering layer of the reinforcement on the road leading under the bridge. The following actions are strongly recommended: replace all bearings; reconstruct the waterproofing of the bridge, roadway, drainage system, expansion join on support no. 4; consider the installation of asphalt expansion joins over support no. 1 and piers no. 2 and 3; clean the entire surface with high-pressure water and apply a remedial coating, that would slow down the corrosion of the reinforcement; renew the areas with the delaminated cover layer with a repair compound.

The conclusions about the calculation of load bearing capacity are based on the current technical condition of the bridge found during diagnostics (08/2021). During further operation, it is necessary to pay attention to the state of prestressing and possible opening of joints at the contact of beam segments.

Keywords: chloride content, load-bearing reinforcement, horizontal transverse displacement, prestressing reinforcement, corrosion of the reinforcement, grouted prestressing tendons.

Introduction. The main task in the immediate future is to shift from the approach of largescale bridge construction to that of equal emphasis on the construction and maintenance of bridges. The deterioration state prediction model of concrete beam bridges was established as the basis by Chinese researches [1], and optimization suggestions were put forward in terms of bridge inspection standards and processes. This method aims to perfect the bridge inspection mechanism. Many researchers from the USA [2, 3] and the EU work in the same direction [4].
\end{abstract}


In 2021, the Department of Concrete Structures and Bridges of the Faculty of Civil Engineering, the Slovak University of Technology in Bratislava, was asked to carry out the technical survey and diagnostics of the bridge on the road of the second class with denotation II/520. The bridge is located in the Rača district at the end of Rybničná Street.

The aim of the inspection and diagnostics was twofold: to obtain data for the assessment of the construction and technical condition of the bridge and to develop a project for its reconstruction.

The task of the diagnostics:

- to inspect all available parts of the structure and determine the type and degree of degradation of each of the bearing element of the substructure and superstructure, as well as the condition of the bridge superstructure;

- to perform a comprehensive mapping of chloride ion contamination of concrete, depths of carbonation, and non-destructive test strength parameters;

- to elaborate the scientific-research analysis of the results obtained and to process the recommendations for reconstruction.

Object and research methods. Description of the bridge structure. It is a three-span bridge made of prestressed prefabricated I-67 beams, 24 meters long. The number of beams in the transverse direction is 11 and in the longitudinal direction they form simple supported spans. The middle span is in the form of a lap joint with fixed bearings on the end of beams span; these are mounted directly on the supports utilizing pot sliding bearings. In the longitudinal direction, the bridge acts as a single expansion unit with non-sliding bearings on the support in the direction of Rača. The expansion joint is only at the support in the direction of Vajnory. Drainage is solved by an efficient dewatering arrangement with an outlet directly to the terrain and the path under the bridge. The beams, in the span between the piers P3 and P4, are, according to the project, rotated in plan concerning the beams in the first two spans by approximately $2^{\circ}$. The beams are switched from several segments. The dimensions of the structure and piers are apparent from the drawings in Fig. 1, 2. The supports and piers are made of reinforced concrete. The bridge was built in 1975.

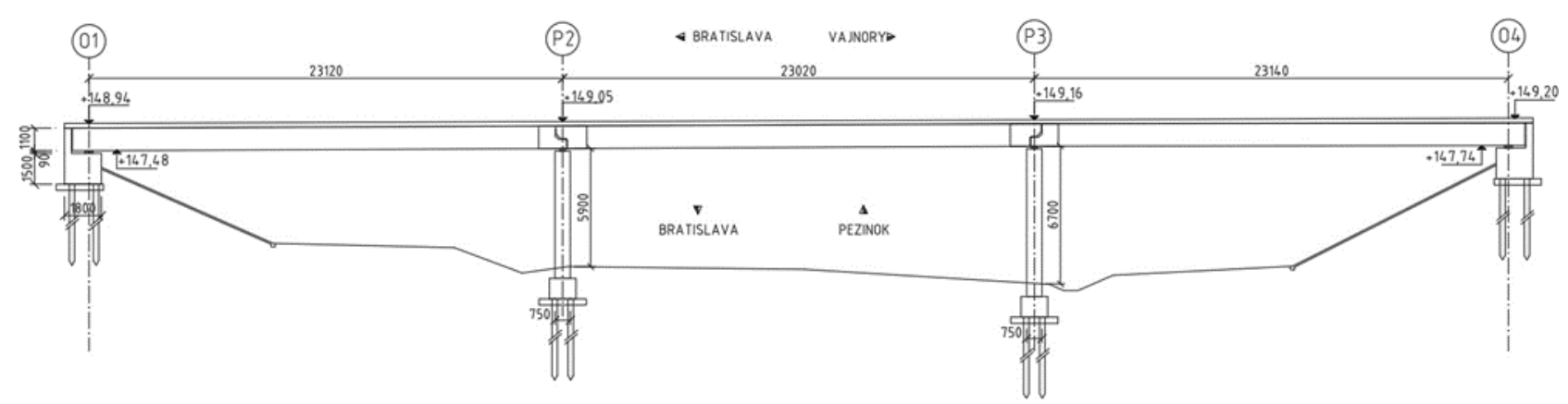

Fig. 1. Scheme of the bridge - longitudinal section

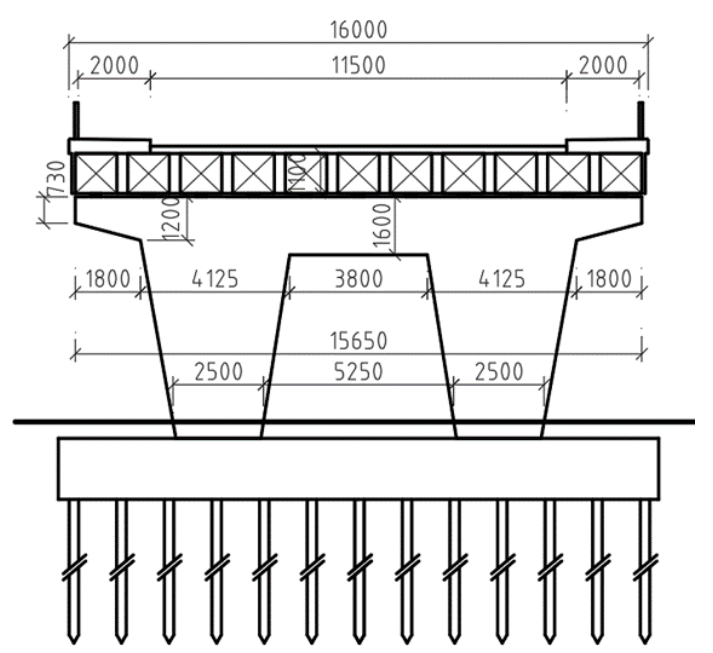

Fig. 2. Bridge cross section (taken from the bridge notebook) 
Condition and recorded failures of the substructure. The supports of the bridge are in satisfactory condition and do not show extensive faults that would indicate problems with statics. On support no. 4, stains are visible due to the intense leakage through the expansion joint, which probably took place before its replacement, since at the time of inspection the wet stains were not observed. The abutment reinforcement has insufficient coverage and the reinforcement corrodes locally. On both supports, the cracks are about 2 to $3 \mathrm{~mm}$ wide due to the corroding reinforcement.

The piers show advanced corrosion of the reinforcement at the flow points, as a result of which the cover layer delamination occurs (Fig. 3). Due to the corrosion of the reinforcement, there are in some places wide longitudinal cracks within the piers head. It is assumed that there is a high concentration of chlorides in these places of the pier, which will continue to cause corrosion of the reinforcement, even if the flow of the piers would stop completely.
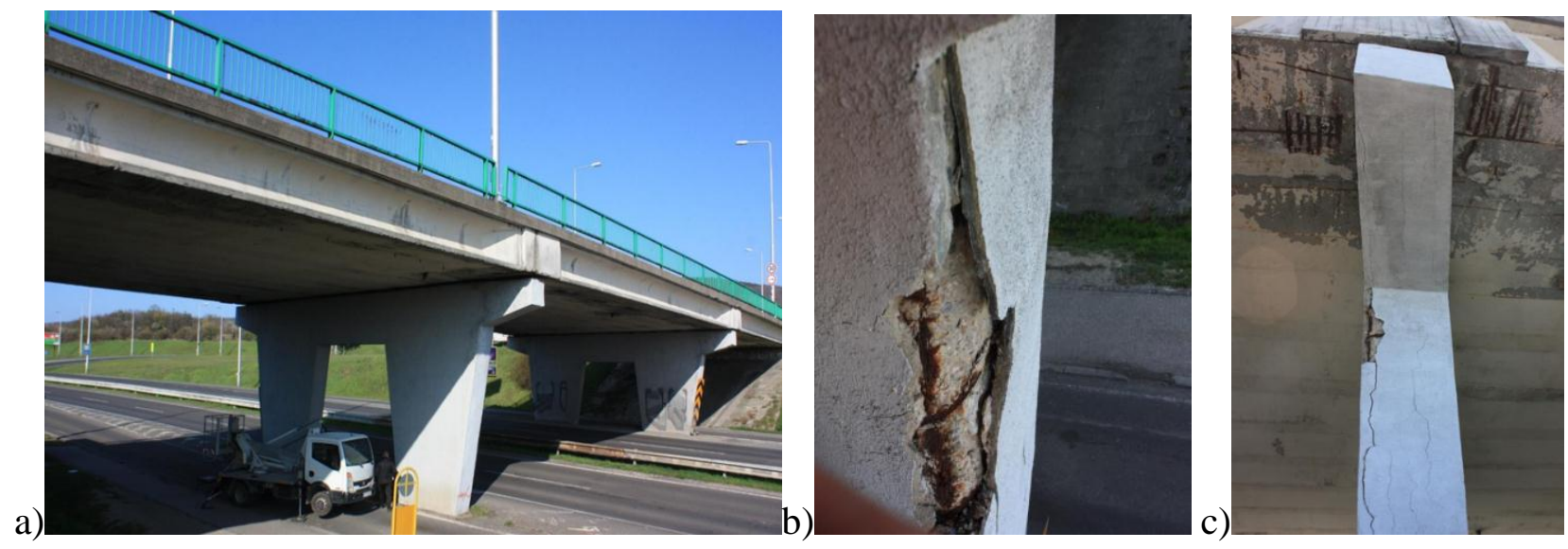

Fig. 3. View of the bridge (a); condition and failures of the substructure (b, c)

Corrosion of the main load-bearing reinforcement within the pier head on the short console is progressing in some places, with a cross-sectional weakening of approximately $30 \%$ with significant delamination of the cover layer, which significantly reduces the cohesion of concrete with reinforcement.

Condition of the superstructure. The most serious failure of the superstructure is its horizontal transverse displacement at support no. 4, which reaches approximately $12 \mathrm{~cm}$. The displacement is evident from the view of the bearings on the support. The bearings are omnidirectional on the support and hence the displacement does not impact the structure. The difference in the size of the expansion joint on the left and right sides of the support also indicates the rotation of the structure in the horizontal plane. The difference in the size of the expansion joint $(15+15=30 \mathrm{~mm})$ geometrically corresponds approximately to the horizontal transverse displacement, which is created by rotating the entire structure of the superstructure of the bridge around the center of the support no. 1 in the horizontal plane. The shift of the structure is also evident on pier no. 3 , the values of the displacements on this pier being approximately $2 / 3$ of the displacements on the support no. 4 which also corresponds to a given rotation of the structure in the horizontal plane around a point in the center of the support no. 1 .

It is not known when the rotation took place, as none of the previous inspections mention this deformation, even though it is a serious inescapable fault. However, the rotation of the structure took place before the coating was applied to the bearings. The shifted bearing surfaces are painted and the new expansion join has probably already been fitted to the deformed structure, as it does not show a significant bevel in the horizontal plane.

The cause of the shift can be thermal stress - since on support no. 4 and there are omnidirectional bearings on the piers, it has nothing to hold the bridge in a horizontal direction perpendicular to the axis of the bridge, apart from friction. The temperature causing the expansion of the bridge could gradually shift the structure (e.g. when blocking the expansion of the bridge only on one side of the support). However, another reason for shifting the supporting structure is

Bulletin of Odessa State Academy of Civil Engineering and Architecture, 2021, no. 84, page 39-48 
also possible. A nationwide problem of the load-bearing structure is insufficient coverage of the reinforcement, which is manifested by significant corrosion of the reinforcement, especially in places that flow, or flowed in the past. In these places, the cover layer delamination occurs, which falls off and endangers traffic under the bridge.

Locally, especially in places of intensive inflow of end beams, reinforcement is exposed and corroded (Fig. 4, a). The exposed prestressing reinforcement has so far been free of corrosion. The controlled tendon ducts were grouted with a fine injection material. There is no local concreting of the anchors of prestressing reinforcements, which corrode intensively (Fig. 4, b). Some beams have a longitudinal crack at the top of the lower flange - it is assumed that this is a manufacturing error.
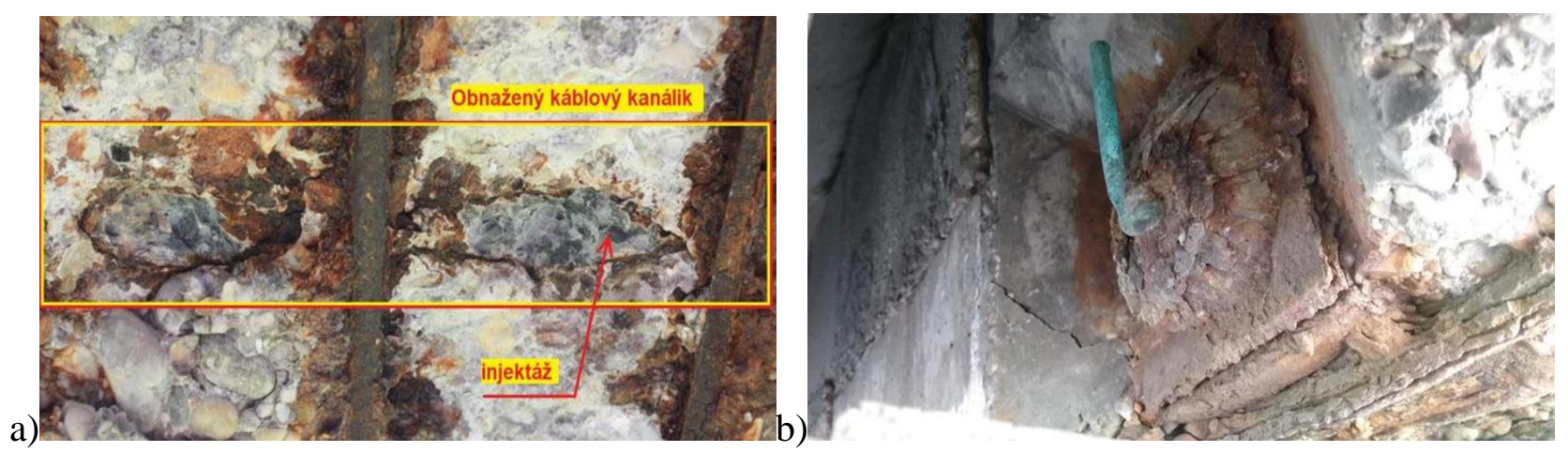

Fig. 4. Intense corrosion of the exposed reinforcement (a); prestressing reinforcement anchor (b)

Intensive leakage of the structure, which occurred during the operation of the bridge (Fig. 5) caused contamination of the structure with chloride ions. It is, therefore, assumed that the corrosion of the reinforcement will continue even if the leakage is eliminated, but the reduction of moisture will significantly slow down the corrosion process. It is therefore necessary to inspect the structure even after heavy rains and to identify places where leaks still occur and repair these places.
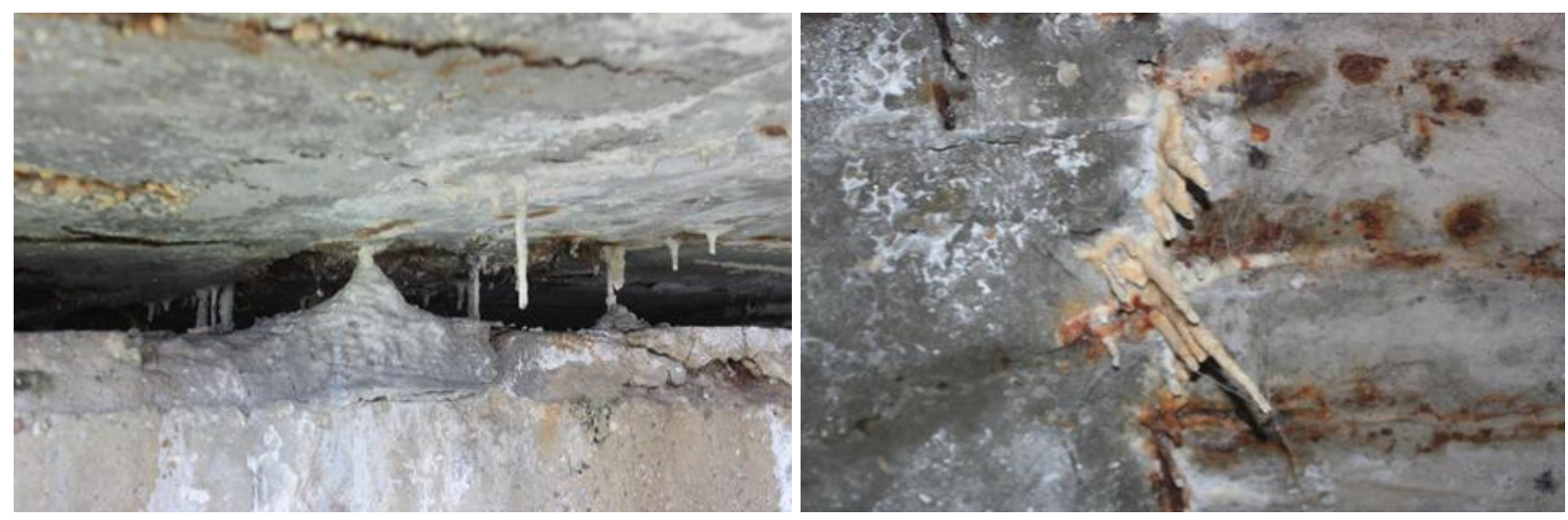

Fig. 5. Intensive leakage of the structure

Some end beams show cracks copying the position of the tendon ducts of the prestressing reinforcement. After drilling them, water leaked from the tendon ducts, which indicates un-grouted tendons. The prestressing reinforcement was not corroded at either point on either of the two tendons (Fig. 6). The sample taken from the inside of the tendon duct showed only a slightly increased concentration of chlorides up to about $0.4 \%$ by weight of the cement. The probe sites were subsequently repaired with a cement-based repair compound. 

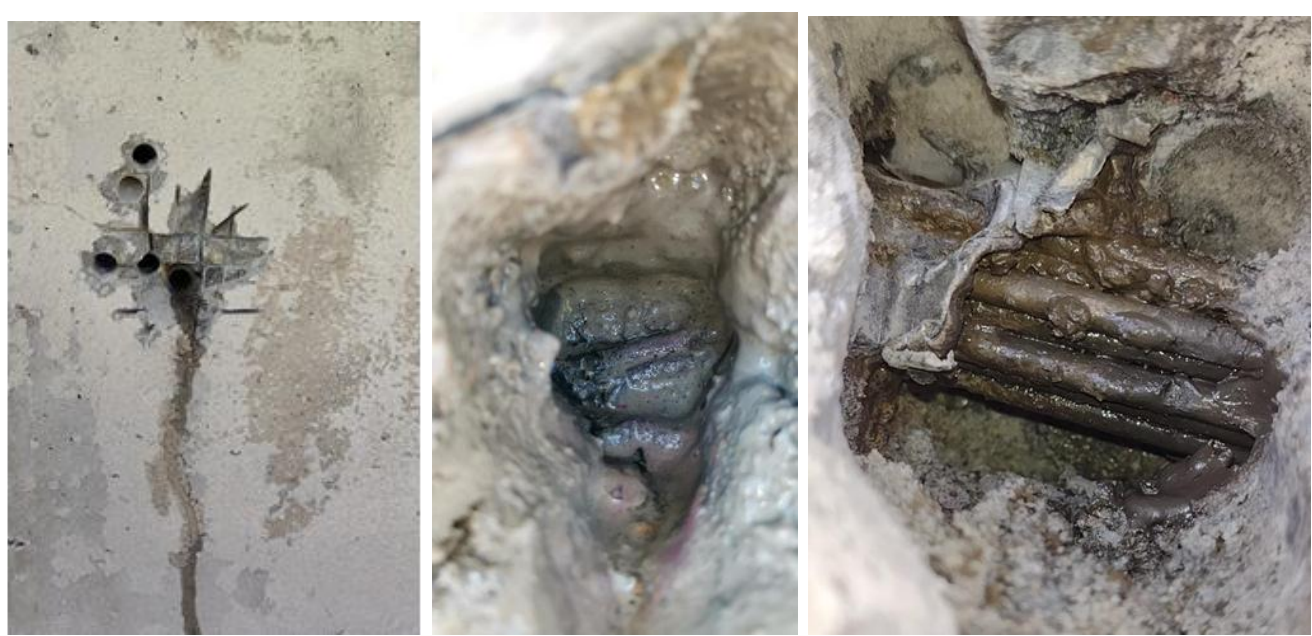

Fig. 6. State of prestressing reinforcement in tendon ducts from which water leaked after drilling

No excessive deflection of the structure or cracks in the middle of the span was observed.

Condition of superstructure and bridge accessories. The most serious failures of the bridge superstructure are displaced bearings due to displacement of the entire superstructure and their advanced deep corrosion. The bearings on the piers and supports are in a state of disrepair. The tooth bearings are also significantly corroded.

Expansion joint at support no. 4 is in poor condition. After a detailed inspection, several failures were found due to the transverse displacement of the bridge. Due to the displacement in the transverse direction, cracks were formed in the rubber of the expansion joint and it has deformed, as well as tearing of the anchor bolts and tearing off the cover plate at the ledges. The expansion join within the roadway also contains several minor faults. For support no. 1 there is no expansion join at this point, a transverse crack was formed in the asphalt.

The drainage of the bridge has been rehabilitated in the past and is functional. The leakage of the structure occurs in the places of their installation, where during the reconstruction their connection to the waterproofing was probably incorrectly made. The problem is the original steel drain pipes, which corrode and are loose - there is a risk of them falling on the road. One steel drain pipe fell out on its own when slightly tapped.

The drainage of the space between the prefabricated parts has been reconstructed and is functional. Locally, mortar falls out between the elements of the slope cladding at the supports.

There are local cracks in the asphalt at the place where the expansion join is installed. Locally, there is also the collapse of the curb, corrosion of the railings, and the collapse of asphalt on the sidewalks.

Non-destructive measurement of concrete strength. Measurements were performed on supports, piers, girders, and reinforced concrete of the bridge with a Schmidt hardness tester type $\mathrm{N}$ on the ground surface at 6 different locations for each of the four structural parts.

The strength determined by the Schmidt hardness tester was evaluated according to STN 731373 [5] and STN EN 13791 [6], using the following factors: 0.85 for dry concrete, 0.9 for old concrete, $1 / 0.85$ considering the determination of strength in the structure. Cylindrical strength was converted from cube to a conversion factor of 0.85 .

The values are partly influenced by the carbonated layer; therefore, we recommend considering a concrete class C 30/37 for the supports, C 35/45 for piers in the calculations. The value of carbonation on the beams is up to $5 \mathrm{~mm}$, so it is possible to consider the measured values of strength according to non-destructive tests. For beams, we recommend considering a concrete class of at least C 40/50 for the calculations. The concrete between the beams is very poorly compacted, which is also reflected in the number of caverns. In the calculations, we are recommending to consider strength class C 25/30. 
Measurement of chloride content in concrete. From the superstructure of the bridge, 20 pairs of samples were taken (different parts, leaked, not wet, surface layer, reinforcement) and 17 pairs of samples were taken from the substructure from different heights above the road and at different depths from the core wells to determine the chloride profile. The results are shown in table 1.

Table 1 - Evaluation of the chloride content within the superstructure (when recalculated to the weight of the cement, a cement dose of $400 \mathrm{~kg} / \mathrm{m}^{3}$ was considered for both beams and grout and

$300 \mathrm{~kg}$ for reinforced concrete. Average values of a pair of samples

\begin{tabular}{|c|c|c|c|c|}
\hline $\begin{array}{c}\text { Indication of the } \\
\text { sampling point }\end{array}$ & $\begin{array}{c}\text { Depth from } \\
\text { concrete surface } \\
(\mathrm{mm})\end{array}$ & $\begin{array}{c}\text { Place of } \\
\text { sampling * }\end{array}$ & $\begin{array}{c}\text { Chloride content } \\
\text { in concrete }(\%)\end{array}$ & $\begin{array}{c}\text { Chloride content } \\
\text { to the expected } \\
\text { cement dose }(\%)\end{array}$ \\
\hline CL1 & $0-10$ & Corroding anchor & 0.176 & 1.0 \\
\hline CL3 & $0-10$ & Beam - Z & 0.437 & 2.6 \\
\hline CL4 & - & Grout - Z & 0.085 & 0.5 \\
\hline CL5 & $0-10$ & Beam - N & 0.033 & 0.2 \\
\hline CL6 & $0-10$ & Beam - Z & 0.677 & 4.0 \\
\hline CL7 & $0-10$ & Beam - N & 0.409 & 2.4 \\
\hline CL9 & $0-10$ & Concreting - Z & 1.655 & 3.0 \\
\hline CL10 & $0-10$ & Beam - N & 0.597 & 0.8 \\
\hline CL11 & $0-10$ & Beam -end - N & 0.134 & 0.5 \\
\hline CL12 & $0-10$ & Beam -end - N & 0.077 & \\
\hline
\end{tabular}

* Z - leaked part, $\mathrm{N}$ - non - leaked part.

The permitted chloride content in concrete in relation to the weight of cement is - for beams and grout: 0.2; for reinforced concrete and substructure 0.4. It is evident that almost all parts of the structure have exceeded the permitted chloride content in the concrete, which inevitably leads to corrosion of the reinforcement (chloride content above $1 \%$ by weight of cement causes corrosion of the steel reinforcement with $100 \%$ probability). In some cases, the permitted chloride content has exceeded 10 to 30 times. Such a high chloride content significantly accelerates the corrosion process of the reinforcement in concrete.

The corrosion process, with a chloride content above $1 \%$ by weight of cement, can no longer be stopped, but it can be significantly slowed down by preventing the penetration of water and moisture to the reinforcement, which has coverage within the superstructure of 0 to $20 \mathrm{~mm}$. The coverage of the pier reinforcement ranges between 60 and $80 \mathrm{~mm}$ (measured on core wells).

Depth of carbonation. Samples from core wells from piers were measured by the depth of carbonation of concrete using a $1 \%$ solution of phenolphthalein. The depth of carbonation of concrete piers is on average 15 to $20 \mathrm{~mm}$. The depth of carbonation on the beams, reinforced concrete, and supports was determined by gradual drilling. Carbonation of beams and reinforced concrete reached values of only 0-5 mm.

Determination of diameters of reinforcement and cover in piers. The thickness of the reinforcement cover, which ranged from 60 to $80 \mathrm{~mm}$, and the reinforcement diameters, which were 16 and $20 \mathrm{~mm}$, were measured on the core boreholes from the piers.

Overall evaluation of the bridge. Load-bearing structure - superstructure. The supporting structure does not show excessive deflection or cracks. However, the entire upper structure is deflected in the horizontal plane by rotating around the center of support no. 1. Deformation at support No. 4 reaches up to $120 \mathrm{~mm}$. It is not clear what caused this deformation, or when exactly it occurred. However, it is evident that the rotation of the structure took place before the coating was applied to the bearings. The expansion join shows a slight bevel in the horizontal plane, which has manifested itself in several failures. It is therefore evident that the shifts in the horizontal plane on support no. 4 probably occurred even after the replacement of the expansion join. A significant problem is the leakage of the structure in the place of the dewatering system which leads to the 
transport of chlorides from the sanding salts to the individual parts of the superstructure. Contamination of concrete with chloride ions causes advanced corrosion of the reinforcement of joints between prefabricated beams as well as beam stirrups at the bottom surface. The chloride content locally exceeds the permitted values 10 to 30 times. Due to the corrosion of the reinforcement, the cover layer delaminates, which endangers traffic under the bridge.

The depth of carbonation on beams and concrete is only minimal (up to $5 \mathrm{~mm}$ ) and thus the corrosion of the reinforcement is not accelerated by the synergistic effect of carbonation and chloride ions. Locally, there is advanced corrosion of the unprotected anchors of the prestressing reinforcement at the site of expansion joints.

Exposed tendon ducts are rare. The inspected tendon ducts at the bottom surface have been injected with a high-quality grout and the prestressing reinforcement show (showed) no signs of corrosion. Probes on the end beams indicate (indicated) insufficient grouting, and after drilling, water has leaked from the tendon ducts. The prestressing tendons in those tendons do (did) not show signs of corrosion, even though the chloride content has exceeded the permissible values by approximately 200 percent (twice).

As these are switched prefabricated parts, the structure is one of the bridges under the high risk category. With this type of structure, if the prestressing tendons are not injected, their corrosion can cause a sudden collapse of the structure over time. It will therefore be necessary to monitor the structure in a stricter mode (inspection focusing on joints between beam segments each year). The strength parameters determined non-destructively indicate relatively high-quality precast concrete as well as reinforced concrete.

Supports and piers. The supports do not show significant defects that could be of static origin. They flow in places, and have flowed significantly before the expansion join was replaced. Locally at the points of flow, the reinforcement corrodes and the cover layer is delaminated.

The bearing reinforcement of the pier head locally shows signs of advanced corrosion with a delaminated cover layer. The chloride content in these places exceeds the permissible values approximately 10 to 20 times. Due to the corrosion of this reinforcement as well as the stirrups, the cross-sections can be significantly weakened.

Bearings. The bearings are in a state of disrepair, in places with advanced corrosion and gradual loss of function. Almost all bearings are deflected by the displacement of the superstructure. The tooth bearings are also significantly corroded.

Expansion join at support no. 4 shows several failures of a smaller extent due to the transverse movement of the bridge. The cover plate on the ledges is loosened with the anchor bolts torn out, probably as a result of the transverse displacement of the bridge and the subsequent bulging of the expansion join. Expansion join at support no. 1 is absent, a crack has formed in the asphalt at the dilatation point.

Bridge superstructure. The curb disintegrates locally. Railings and public lighting poles corrode. The original drainage pipes are corroded and are in danger of falling onto the road under the bridge. In the places of drainage systems, the supporting structure leaks.

Evaluation of load capacity. Corrosive losses at prefabricated joints are rarely up to $100 \%$ and within the lower branch of prefabricated stirrups only up to $10 \%$. The overvoltage within the beams can be considered with a $100 \%$ value according to the project (without signs of corrosion).

In terms of long-term use of the bridge (SLS serviceability limit states), 2 load capacities were determined. The first with consideration of the factor $r_{k}=1.0$ and the second with consideration of $r_{k}=r_{k}$, inf $=0.9$. By reducing the preload value by $10 \%$, uncertainties in determining the magnitude of the preload force are considered. Since the prestressing diagnosis did not reveal corrosion of the prestressing reinforcement, we recommend considering the loads determined with $\mathrm{r}_{\mathrm{k}}=1.0$ when the normal load capacity is $V_{n}=23.8$ tons and the exclusive load capacity $V_{r}=75.7$ tons.

From the point of view of the medium-term use of the bridge (ultimate limit states - ULS), it is possible to consider a normal load capacity $V_{n}=34$ tons, an exclusive load capacity $V_{r}=116$ tons and an exceptional $\mathrm{V}_{\mathrm{e}}=358$ tons. 
Results of the research. In accordance with the valid regulations, due to the significant deformation in the horizontal plane, the cause of which is not known and due to the gradual loss of the bearing function, I evaluate the construction, and technical condition by the degree: VI. VERY $B A D$ technical condition of the bridge must be solved immediately (reconstruction project, renovation of the building).

Conclusions and Recommendations: The service life of the bridge is mainly affected by corrosion and displacement of the bearings, as well as contamination of concrete with chlorides from sanding salts and corroded bearings. Corrosion of the reinforcement in the horizon of 5 years can negatively affect the load-bearing capacity of the bridge and there is also an increased risk of falling pieces of the covering layer of the reinforcement on the road leading under the bridge. The following actions are strongly recommended:

- rehabilitation of the bridge as soon as possible, and development of a project for the reconstruction of the bridge and execute a complete renovation of structures;

- operation of the bridge under a highly strict inspection mode (inspection focusing on joints between beam segments every year) due to the type of bridge (bridge of prestressed switching prefabricated parts) and due to the fact that insufficiently injected prestressing tendons were discovered during diagnostics.

\section{Reconstruction proposal:}

- replace all bearings;

- reconstruct the waterproofing of the bridge, roadway, drainage system, expansion join on support no. 4, railing;

- consider the installation of asphalt expansion joins over support no. 1 and piers no. 2 and 3;

- clean the entire surface with high-pressure water and apply a remedial coating, that would slow down the corrosion of the reinforcement due to insufficient coverage;

- renew the areas with the delaminated cover layer with a repair compound;

- examine removal of degraded concrete and passivation of the environment around the concrete reinforcement, reprofiling of the covering concrete layer, in all critical areas of the bridge.

The conclusions about the calculation of load bearing capacity are based on the current technical condition of the bridge found during diagnostics (08/2021 [7]). During further operation, it is necessary to pay attention to the state of prestressing and possible opening of joints at the contact of beam segments.

\section{References}

[1] Su D, Liu Y, Li X, Cao Z, "Study on optimization of inspection mechanism of concrete beam bridge", PLoS ONE 16(8): e0256028, 22p, 2021. doi.org/10.1371/journal.pone.0256028.

[2] Filippos Alogdianakis, Loukas Dimitriou, Dimos C. Charmpis, "Pattern Recognition in Road Bridges' Deterioration Mechanism: An Artificial Approach for Analysing the US National Bridge Inventory", Transportation Research Procedia 52, pp.187-194, 2021. doi: 10.1016/j.trpro.2021.01.021.

[3] Akshay Kale, Brian Ricks, Robin A Gandhi, "New Measure to Understand and Compare Bridge Conditions Based on Inspections Time-Series Data", J. Infrastruct. Syst. 27(4): 04021037, 13p, 2021. doi: 10.1061/(ASCE)IS.1943-555X.0000633.

[4] Ivan Janotka, Michal Bačuvčík, Peter Paulík, "Low carbonation of concrete found on 100year-old bridges", Case Studies in Construction Materials 8, pp.97-115, 2018. doi: 10.1016/j.cscm.2017.12.006.

[5] STN 731373. Testing of concrete by hardness testing methods [24.12.1981]. Slovak Republic. ICS:19.020, 91.100.30. 
[6] STN EN 13791. Assessment of in-situ compressive strength in structures and precast concrete components [1. 11. 2020]. Slovak Republic. ICS: 91.080.40.

[7] Halvonyk Y., Borzovič V. "Load capacity of the bridge no. M 044 at the end of Rybničná street above the road II / 502 Bratislava-Pezinok", Technical report. Bratislava, STU, 2021. 134p.

\title{
ОЦЕНКА ТЕХНИЧЕСКОГО СОСТОЯНИЯ МОСТА № М 044 В КОНЦЕ УЛИЦЫ РЫБНИЧНОЙ НАД ДОРОГОЙ ІІ / 502 БРАТИСЛАВА-ПЕЗИНОК
}

\author{
${ }^{1}$ Паулик П., к.т.н., доцент, \\ peter.paulik@stuba.sk, ORCID: 0000-0003-1051-3988 \\ ${ }_{1}^{1}$ Словацкий технический университет в Братиславе \\ Radlinského 11, Братислава, 81005, Словацкая Республика \\ ${ }^{2}$ Чернева Е., к.т.н., доцент, \\ chernieva@ogasa.org.ua, ORCID: 0000-0002-4807-6421 \\ ${ }^{2}$ Одесская государственная академия строительства и архитектуры \\ ул. Дидрихсона 4, г. Одесса, 65029, Украина
}

\begin{abstract}
Аннотация. Статья посвящена результатам обследования и диагностики моста № М 044 в конце улицы Рыбнична над дорогой II / 502 Братислава-Пезинок в Словацкой Республике. Статья является результатом совместной деятельности Кафедры бетонных конструкций и мостов Словацкого Технического Университета в Братиславе и Кафедры железобетонных конструкций и транспортных сооружений Одесской государственной академии строительства и архитектуры в рамках Национальной стипендиальной программы Словацкой Республики. В результате проведенных испытаний были получены данные для оценки технического состояния отдельных конструкций и моста в целом. В результате осмотра был определен тип разрушения каждого элемента конструкции каркаса и надстройки. Проведены исследования на содержание хлоридно-ионного загрязнения бетона и неразрушающие испытания прочностных параметров. В соответствии с действующими нормативами, из-за значительной деформации в горизонтальной плоскости, причина которой не известна, и из-за постепенной потери несущей функции, конструктивно-техническое состояние оценивается как VI - очень плохое и требует проведения немедленной реконструкции.
\end{abstract}

На срок службы моста повлияла коррозия и смещение подшипников, а также загрязнение бетона хлоридами. Коррозия арматуры в течении последующих 5 лет может негативно повлиять на несущую способность моста, а также существует повышенный риск падения кусков защитного слоя бетона на дорогу. В результате были предложены следующие рекомендации по восстановлению моста: заменить все подшипники; восстановить гидроизоляцию моста, проезжей части, дренажной системы, покрытия моста на опоре № 4; рассмотреть возможность установки асфальтобетонного покрытия над опорой № 1 и столбов № 2 и 3; очистить всю поверхность водой под высоким давлением и нанести корректирующее покрытие, замедляющее коррозию арматуры; обновить участки с отслоившимся покровным слоем ремонтным составом.

Выводы о расчете нагрузок основываются на текущем техническом состоянии моста, обнаруженном в ходе диагностики (08/2021). При дальнейшей эксплуатации необходимо обращать внимание на состояние предварительного напряжения и возможное раскрытие стыков при контакте сегментов балки.

Ключевые слова: содержание хлоридов, несущая арматура, горизонтальное поперечное смещение, предварительно напряженная арматура, коррозия арматуры, вводимые предварительно напряженные кабели. 


\title{
ОЦІНКА ТЕХНІЧНОГО СТАНУ МОСТУ № М 044 В КІНЦІ ВУЛИЦІ РИБНІЧНОЙ НАД ДОРОГОЮ І / 502 БРАТИСЛАВА-ПЕЗИНОК
}

\author{
${ }^{1}$ Паулік П., к.т.н., доцент, \\ peter.paulik@stuba.sk, ORCID: 0000-0003-1051-3988 \\ ${ }^{1}$ Словачкій технічний університет в Братиславі \\ Radlinského 11, Братислава, 81005, Словацька Республіка \\ ${ }^{2}$ Чернсва О., к.т.н., доцент, \\ chernieva@ogasa.org.ua, ORCID: 0000-0002-4807-6421 \\ ${ }^{2}$ Одеська державна академія будівництва та архітектури \\ вул. Дідріхсона 4, Одеса, 65029, Україна
}

Анотація. Стаття присвячена результатам обстеження і діагностики моста № М 044 в кінці вулиці Рибнічна над дорогою II / 502 Братислава-Пезинок в Словацькій Республіці. Стаття $\epsilon$ результатом спільної діяльності Кафедри бетонних конструкцій $\mathrm{i}$ мостів Словацького Технічного Університету в Братиславі та Кафедри залізобетонних конструкцій i транспортних споруд Одеської державної академії будівництва та архітектури в рамках Національної стипендіальної програми Словацької Республіки. В результаті проведених випробувань були отримані дані для оцінки технічного стану окремих конструкцій і моста в цілому. В результаті огляду було визначено тип руйнування кожного елемента конструкції каркасу і надбудови. Проведено дослідження на вміст хлоридно-іонного забруднення бетону і неруйнівні випробування параметрів міцності. Відповідно до чинних нормативів, через значну деформацію в горизонтальній площині, причина якої не відома, і через поступову втрату несучої спроможності, конструктивно-технічний стан оцінюється як VI - дуже поганий і вимагає проведення негайної реконструкції.

На термін служби моста вплинула корозія i зміщення підшипників, а також забруднення бетону хлоридами. Корозія арматури протягом наступних 5 років може негативно вплинути на несучу спроможність мосту, а також існує підвищений ризик падіння шматків захисного шару бетону на дорогу. В результаті були запропоновані наступні рекомендації по відновленню моста: замінити всі підшипники; відновити гідроізоляцію мосту, проїзної частини, дренажної системи, покриття моста на опорі № 4; розглянути можливість установки асфальтобетонного покриття над опорою № 1 і стовпів № 2 і 3; очистити всю поверхню водою під високим тиском і нанести коригуюче покриття, що сповільнює корозію арматури; оновити ділянки з відшаруванням старого захисного шару бетону ремонтним складом.

Висновки про розрахунок навантажень грунтуються на поточному технічному стані моста, виявленому в ході діагностики (08/2021). При подальшій експлуатації необхідно звертати увагу на стан попереднього напруження і можливе розкриття стиків при контакті сегментів балки.

Ключові слова: вміст хлоридів, несуча арматура, горизонтальне поперечне зміщення, попередньо напружена арматура, корозія арматури, попередньо напружені кабелі.

Стаття надійшла до редакції 06.09.2021 